\title{
Ethno-cultural Foundations of Culture, Art and Education in the Context of Modern Educational Space
}

\author{
Lyudmila Mikheeva \\ Russian state Specialized Academy of Arts \\ Moscow, Russia \\ E-mail: lira191m@gmail.com
}

\begin{abstract}
In the article the author substantiates the necessity of accepting a spiritual heritage of our people, the riches of folk culture, to study which is vital in the moral and Patriotic education of youth, in the formation of moral compass, and emotional responsiveness, the development of creative talents.
\end{abstract}

Keywords-national culture; holidays; traditions; crafts of the peoples of Russia; moral and Patriotic education of youth

\section{INTRODUCTION}

We live in a complex and diverse world in which human communities are becoming more committed to universality, but universality is realized only as a unity of diversity of cultures. Without the support of spiritual and moral values of their homeland, it is impossible to realize this, as it is impossible to educate the citizen and patriot.

Special, from the heart and soul of reaching the adoption of the traditions, values, forms of cultural, historical, social and spiritual life of every corner of the small country filled with concrete, sensual, imaginative content through family, relatives, friends, school, nature. It is possible only when the very concept of "father's house", "native land", "my family and the family", "homeland" will be included in the human consciousness from an early age, and then gradually it will grow up, and his civic consciousness and patriotism will gain a vivid specifics. Russian culture can be compared with the trunk of a mighty tree, whose roots form the culture of the peoples of Russia. Knowledge of ethnic and cultural traditions to which a person belongs by origin, is an important moment in his spiritual-moral development and education.

\section{THE CARRIERS OF CULTURAL VALUES AND TRADITIONS OF THE PEOPLES OF RUSSIA}

Bearers of cultural values and traditions of the peoples of Russia. The moral health of our society, its longevity largely depend on whether we will manage to keep the truly invaluable wealth, which is folk art. Rooted in antiquity, that it connects the past and the future. Therefore, we must preserve him from oblivion and neglect. Folk art is shaped by our memory, our gene pool. And memory is always accompanied with the concept of "conscience".

Many priorities of the past years has transformed or even disappeared, but as you know, "Holy place is never empty". Not formed niche left unattended, relying on "maybe", that all somehow itself will be filled with what is necessary. This position is indifference, and it leads to spiritual stagnation and to the fact that flourishing a lack of spirituality, vulgarity, selfishness - are deeply alien, in fact the mentality of the Russian people. That this did not happen, we must act together, as they said in the old days - "all the world".

\section{THE NEED TO APPEAL TO SPIRITUAL HeRITAGE OF OUR PEOPLE}

In modern conditions of unusually increased the need for recourse to the spiritual heritage of our people, the wealth of folk culture, to study which is the primary goal in the moral, Patriotic upbringing of the younger generation. In the richest folk crafts embodied the historical memory of generations, embodied the soul of the people who created genuine masterpieces of art, which testify to the talent and high artistic taste of the craftsmen. The education of full of personality, development of moral potential, aesthetic taste of children and adolescents is impossible, if we talk about it in the abstract, without entering young people in the peculiar, vivid, unique world that for centuries has created the fantasy of the Russian people. The best qualities of the national character: respect for its history and traditions, love of the homeland in General and to native land in particular, chastity, modesty, an innate sense of beauty, the pursuit of harmony - all these are creations of craftsmen.

\section{KNOWLEDGE OF HistORY, NATIONAL CULTURE - THE KEY TO THE FUTURE OF THE COUNTRY}

The future of the country and the people depends entirely on what his descendants, sons and daughters. And so they would become worthy citizens, he loved the Fatherland, not in words but in reality, they should know their history, national culture, preserve and develop folk traditions. Russian history is complex, difficult, heroic. Our culture is rich, its spirit strong. Russia's great past and her future, too, 
should be great. Young generation's heart and soul are to understand their culture, tenderly loving the Motherland, which has become special, special, a pure soul.

The vicissitudes of history, difficult trials that befell her, Russia has stood with honor, and never to demean his dignity. Courageous, tempered, noble and beautiful country. And her heart generous, sympathetic on kindness and beauty. The Russian people are truly worthy of their homeland. And our children should be aware of this, bear in mind and the feelings of their unquenchable light of Faith, Truth, Kindness, Love and Hope. Their knowledge, their spiritual culture affects our common future.

\section{APPEAL TO THE ORIGINS OF ART - FOLK ART}

How to educate the younger generation so that the love for the Motherland was not just beautiful, sonorous phrase, and determined the inner essence of a young man? What can be done if there are no performances, revealing in a bright, figurative form of a Patriotic theme, ideas? Here, obviously, we need a comprehensive, systematic approach to solving problems of moral and aesthetic, Patriotic education.

Russia has a great, light-filled soul. It reflected in its nature, in art: in songs, dances, music and word.

Time itself dictates the need to refer to the sources of art - work created by the genius of the people. Folklore in all its genres reveals facets of the rich and unique Russian soul. To store, to preserve, increase people's creativity, to develop its traditions - a sacred duty of teachers, artists.

Folk dances, song and other genres of folklore, works of folk craftsmen awaken the human soul, giving vent to such feelings which necessarily forgotten in our time, with its speed, randomness, pressure, invasion of life that is alien to our mentality. And this is something that lives, but hidden in the depths of the soul: the subtlety of perception of the world, lyricism, modesty and collectivism, mutual assistance, willingness to help others, compassion and mercy, optimism, openness to the world and people.

Set "Basic educational program primary education" goal is "to provide opportunities to obtain quality primary and basic education" is implemented (as a way) "organization of extracurricular activities, presents a system of programmes based on cognitive interests of younger students and their individual needs." The organization of the activities aimed at the development of students "abilities to produce knowledge" by "meta-actions leading search of information, work with it, adequately supplied with teaching and learning task". The objective of the program is also "appropriate use of mental operations (analysis, comparison, generalization, comparison, etc.), development of thinking, speech, imagination, perception and other cognitive processes". Established universal learning actions are a prerequisite for the development of a sufficient level of General educational skills.

Objectives aimed at spiritual and moral development of students, instilling in them moral values, tolerance, the correct assessment of the events occurring in the world. This aspect of educational institutions is realized in the process of studying academic subjects "Literary reading", "Bases spiritually-moral culture of the peoples of Russia", as well as programs of extracurricular activities of pupils, "Holidays, traditions and crafts of the peoples of Russia". Special attention is focused on formation at students of interest in folk art, spiritual and moral upbringing of culture and tolerance, patriotism and citizenship, the development of artistic taste.

Formation of educational activity of the student is achieved by the use of such means of training in system "the Elementary school of the XXI century", which specifically focused on the development of components of educational activity; ability to learn, the development of cognitive interests and intrinsic motivation, elementary reflective qualities, the formation of self-control and self-esteem of the student.

\section{CONCLUSION}

Reversing the younger generation to the study of holidays, traditions and crafts of the peoples of Russia, attaching them to the rich folk culture, we contribute to the formation of civic consciousness and patriotism, respect for different view, history and culture of the peoples of Russia and the formation of moral values, tolerance, the correct assessment of the events occurring in the world. While we pay close attention to the issues of additional education, extracurricular activities of students, following certain principles of natural law, of conformity to culture, socialization of youth. Forms of work can be varied: visits to fairs, exhibitions, museums, excursions. For example, it can be lectures in the Houses of folk creativity, where experienced lecturers, guides are introduced to traditional folk costume, revealing the functional nature of clothing, its aesthetics, the symbolism of the ornaments, amulets. Very useful to familiarize with traditional cuisine, spiritual-moral basis of the family holidays, of the peasant calendar holidays. Of immense importance, familiarity, learning, development of the wealth of Russian folk Handicrafts, which help to understand better the mentality, the soul of the people, his artistic taste. The art of Gzhel, Khokhloma, Zhostovo, pavlogoradsky shawls, clay toys (Vyatka, Ekaterinburg) is deeply ingrained in folk memory, consciousness and is the basis for the revival of Handicrafts in the modern world. Folk games, songs, and oral folklore, folk dances alive forever, because in songs, dances, dancing manifests a sense of unity, of friendship, are the theme of work, beauty, nature, love. Without the spiritual maturity of youth, formation of moral reference points, without this it is impossible patriotism education, introduction of young people to the ideals of freedom, goodness, fairness, and emotional responsiveness and responsibility for their actions, the development of creativity and ecological culture.

\section{REFERENCES}

[1] Collection of programs of extracurricular activities (grades 1-4), ed. F Vinogradova. - M., ed. Center "Ventana-Graf"; 2011 
[2] Zakharov V. M. "The Poetry of Russian dance", 5 volumes, a - M, $2008-2011$

[3] Mikheeva L. N. Russian folk holidays. - M., Drofa-PLYUS, 2007

[4] Russian traditions and holidays. Reader "Fatherland". - M., DrofaPLYUS, 2007 /Mikheeva L. N., Korotkova M. 